\title{
Abstracts of Papers Presented at the Annual Meeting
}

\author{
SESSION 1A: PUSHING AND PULLING: THE PROCESS OF MIGRATION
}

\begin{abstract}
Mexican Immigrants to the United States: Evidence on Selection and Economic Performance from 1910-1990
\end{abstract}

This study analyzes changes in education and wage performance of Mexican immigrants from 1910 to 1990 and the factors that have contributed to the selection of these immigrants from their population of origin. The study uses data from the Immigration Commission Report of the Commissioner General of Immigration from 1910 to 1930 and from the Mexican and U.S. censuses for 1910 to 1990 . Mexican immigrants are found to be either more educated or as educated as their population of origin. The education advantage of immigrants has decreased over time with the exception of 1960 to 1970. Earnings of Mexican immigrants relative to native whites have declined over time. Lower costs of transportation, the growth of Mexican enclaves in the United States, and the Bracero program were associated with decreases in the skill of immigrants. The introduction of the literacy test in the United States in 1917 and the Mexican Revolution (1910-1920) were associated with increases in the skill level of immigrants.

Zadia Feliciano, Queens College, CUNY

\section{Patterns of Import Trade and Immigration in the Late Nineteenth-Century United States}

The connection between immigrants and international trade in goods is explored in this paper using a modified gravity equation. We determine that during the period 1870 to 1910 the stock of immigrants living in the United States had a positive effect on imports from their respective home countries. Commodity imports are considered for 56 individual commodities from 17 countries. We use a measure of relative income similarity to determine if a Linder-type relationship exists, where a country tends to trade with other countries that have similar tastes as indexed by per capita income. Migrant stock and the relative income coefficients imply that imports are greater from those countries that have similar per capita incomes and have a stock of immigrants living in the United States. The standard gravity equation variables-distance and population-exhibit the expected relationship with imports.

\section{James A. DunleVy and WiLliam K. HutChInSON, Miami University}

\section{To Part or Not to Part: Emigration and Inheritance Institutions in Nineteenth-Century Hesse-Cassel}

This paper examines whether the principle inheritance institutions of western German principalities, specifically partible inheritance and primogeniture, influenced the propensity to emigrate. In an analysis of emigration from the principality of Hesse-Cassel in the $1840 \mathrm{~s}$ and 1850 s, I suggest that such traditions have an influence on the resulting economic structure of a village. Inheritance tradition primarily affects occupational choice and personal wealth and thus produces distinct economic outcomes for peasants. Given these outcomes, the attraction to the migration option varies across village type. Although families and individuals found important reasons to leave under both systems, it is the primo- 
geniture institution that better promotes emigration, providing support for Habbakuk's 1955 prediction in this JOURNAL that the primogeniture institution would be responsible for higher rates of emigration. Further, institutional variations manifest themselves in somewhat diverse pattems of individual emigrant characteristics. In comparison to emigrants from partible villages, I find that emigrants from primogeniture villages took less cash with them, were slightly younger, and more likely to be single.

SIMONE WEgGE, Lake Forest College

\section{SESSION 1B: VIOLENCE AND THE FRUITS OF THE LAND}

\section{Property Rights and Land Conflict: A Comparison of Settlement of the U.S. Western and Brazilian Amazon Frontiers}

This paper examines land conflicts on two similar frontiers-nineteenth-century United States and twentieth-century Brazil. In the United States disputes occurred between homesteaders and large ranchers, who informally claimed large areas of government land. The informal claims of ranchers conflicted with the formal (legal) claims of homesteaders. Without consistent government enforcement of either the informal rights of ranchers (recognizing the customs of the region) or the formal rights of homesteaders (enforcing allocations under the land laws), conflicts between the two ensued. In Brazil disputes have occurred between large title holders and squatters who have invaded their land. Squatters occupy titled, unused land. Violence occurs when land owners attempt to evict squatters. In Brazil the federal government has not consistently enforced the property rights of large claimants. We use data on illegal fencing as an indication of areas of potential conflict between ranchers and homesteaders in the United States and survey data on land expropriations to test hypotheses about land conflicts on the two frontiers.

LEE J. ALSTON, University of Illinois and NBER, GARY D. LIBECAP, University of Arizona and NBER, AND BERNARDO MUELLER, University of Brasilia

Land Tenure Arrangements in Post Gold Rush California: Patterns of Conflict and Cooperation

This paper seeks to explain why potentially beneficial private-order institutions may not emerge by examining a specific examplo-relations between squatters and the owners of land grants in California during the 1850s and 1860s. Despite the apparent benefits to both sides to entering into land tenure contracts, there was a low incidence of such contracts. More commonly tensions devolved into violence. Historical explanations have focused on ideological differences as a reason for squatting and, by extension, the failure of bargaining and subsequent violence. This paper finds bargaining failed neither for the usual economic reasons — political action, distributional issues, or transactions costs-nor for ideological reasons but rather because of externalities created by the existence of other squatters and owners and by squatters' beliefs about what would happen if they rejected a voluntary contract. Violence followed as squatters tried to force owners to compensate them for their improvements. 
Comparing Cherokee and White Agriculture in the Southeastern Upcountry Circa 1840: Are There Lessons for Today's Developing Indigenous People?

The Cherokee removal of 1838 can be framed as the outcome of competition between special interests pitting those who strongly opposed removal against those who favored removal. The Cherokees aimed to preserve their rights to ancestral lands that provided them with significant surplus production in the 1830 s. Whites in Georgia and Alabama aimed to appropriate these surpluses for themselves via a removal policy enforced by the federal government. Using the 1835 Census of the Cherokees and 1840 census data for whites in Georgia and Alabama, I show that the spatial distribution of Cherokee surplus production in Georgia and Alabama in 1835 is matched by heavy influxes of white settlers and slave capital by 1840 in regions where Cherokee surplus production had been the greatest. The overwhelming migration of whites into Cherokee territory in the late 1830s suggests that the minority of Cherokees who signed the removal treaty and left quickly had adopted a cost-minimizing strategy in the face of an inevitable forced migration. The paper concludes with some brief observations regarding the relevance of Cherokee strategies for coping with encroachments by whites for the indigenous people of Peru and Mexico today.

DAVID M. WISHART, Wittenberg University

\section{PLENARY SESSION: GROWTH FROM A COMPARATIVE PERSPECTIVE}

\section{Real Income and Economic Welfare Growth in the Early Republic or Another Try at Getting the American Story Straight}

The latest set of "controlled conjectures" about the course of growth of real GDP per capita in the United States during 1790 and 1840 is produced by using new estimates of aggregate and sectoral labor inputs on a full-time equivalent manhours basis. Incorporating recent revisions of the trend of agricultural labor productivity, and explicit allowances for home manufacturing and value of farm improvements, these comprehensive estimates indicate substantial stability of the growth rate over the long-swing periods 1800 to 1835 and 1835 to 1855 . In this respect they resemble the findings of Abramovitz and David (1973) and Wiss (1992). But they reject the Kuznetian tradition that viewed agriculture as a sector of comparatively low labor productivity and supposed that the reallocative effects of the relative expansion of nonagricultural pursuits contributed to improving the standard of living in the early history of the Republic.

PAUL DAVID, Stanford University

\section{Institutions and Economic Growth: Econometric Evidence for Postwar Europe}

The quarter century that ended around 1973 was a golden age of economic growth in Western Europe. Real GDP rose nearly twice as rapidly as over any comparable period before or since. The elements of Europe's growth miracle-wage moderation, high investment, and rapid export growth — were delivered by a tailor-made set of domestic and international institutions: on the domestic side the social market economy and on the external side international agreements and supranational institutions-that solved problems of commitment and cooperation that would have otherwise hindered the resumption of growth. This paper presents evidence on the effects of those institutions. It reports econometric support for the notion that the centralization and concentration of wage bargaining and membership in intra-European institutions like the European Payments 
Union and the European Coal and Steel Community contributed importantly to the postwar growth miracle.

BARRY EICHENGREEN, University of California, Berkeley

\section{Factor Endowments, Institutions, and Differential Paths of Growth among New World Economies}

We adopt a comparative approach to the study of New World economies to begin to identify and explore systematic patterns in the evolution of institutions and their influence on paths of economic growth. Virtually all colonies established by the Europeans in the Americas began with relatively high levels of per capita income, but factor endowments and other initial conditions contributed to the emergence of substantial differences across them in the distribution of wealth, human capital, and political power. This sharp and early contrast in the extent of inequality had profound and enduring impacts on the structure of the respective colonial economies and ultimately on their long-run paths of institutional and economic development. While European colonies in the Caribbean, Brazil, and the southern colonies on the North American mainland developed extreme inequality, because their climates and soils were well suited for growing crops most efficiently produced on large slave plantations, inequality in Spanish America resulted from the dominance of a relatively small elite of European descent over a large population of Native Americans. The northern regions of North America, in contrast, spawned rather deviant economies with relatively homogenous populations, as well as more equal distributions of wealth and political power. These contrasts in equality persisted over time and may have contributed to differences in the economic institutions that evolved across the respective economies.

STANLEY L. ENGERMAN, University of Rochester and NBER AND KENNETH L. SOKOLOFF, University of California, Los Angeles and NBER

\section{SESSION 2A: ORGANIZATION, TECHNOLOGY, AND PRODUCTION}

\section{Were the Good Old Days that Good? Evolution of Managerial Stock Ownership and} Corporate Governance since the Great Depression

This paper studies how managerial ownership and governance structures of publicly traded corporations have evolved since the Great Depression. Despite the widespread view from Berle and Means (1932) onward that ownership of firms is increasingly separated from managerial control of those firms, almost no research has studied ownership over time. Using a previously neglected 1935 Securities and Exchange Commission ownership survey, which provides the earliest available source on ownership for U.S. firms, we compare managerial ownership and other firm characteristics for the universe of 1,500 exchange-listed firms in 1935 with 5,000 exchange-listed firms today. Contrary to Berle and Means, we find that ownership by officers and directors has risen from 13 percent to 22 percent between 1935 and 1955 . We then investigate possible explanations for the increase in managerial ownership. Whereas the relationship between ownership and performance appears to be very similar in the two periods, we find that the high volatility of the financial markets earlier in the century may be an important factor contributing to lower managerial ownership then than now.

Clifford G. Holderness, Boston College, Randall S. KROSZnER, University of Chicago, AND DENNIS P. SHEEHAN, Pennsylvania State University 


\section{What Actually Happened at Highland Park? Microeconomic History and the Coming of Mass Production}

This paper considers the most famous and dramatic example of firm-level productivity growth this century, the coming of mass production manufacturing methods to the automobile industry at the Ford Motor Company in the years preceding World War I. The sources are newly discovered high-frequency intracompany operating and asset statistics running from 1909 to 1914 and recent work in the history of automobile manufacturing technology. Ford is studied intensively and compared statistically both to the rest of the industry as a whole and to other individual companies. The techniques developed at Ford had an unusually large impact on productivity. The growth came in bursts; mass production was not One Big Thing. The bulk of the growth came before rather than after the introduction of moving assembly lines

DANIEL RAFF, Wharton School, University of Pennsylvania

The Internationalization of Technology, 1874-1929: Evidence from U.S., British, and German Patent Experience

The post-World War II period has seen a great deal of cross-national patenting, reflecting the international character of technology. But in earlier periods, foreign residents received a much smaller share of patents. This paper uses patent data from the United States, Britain, and Germany to explore the internationalization of technology from 1874 through 1929. By means of newly constructed data sets, we show that cross-national patenting varied greatly by industry in both extent and country of origin. We argue that technology internationalized to a greater extent in industries where technology was more generic, especially science-based industries, that developed in relation to international scientific communities; where managerial firms developed; and where a larger share of output went to foreign markets. Such internationalization was often uneven and dominated by firms from the United States, Germany, or both.

ROSS THOMSON, University of Vermont AND

RICHARD R. Nelson, Columbia University

\section{SESSION 2B: LABOR MARKETS DURING THE INDUSTRIALIZATION PROCESS}

\section{The Influence of London on Labor Markets in Southern England, 1830-1914}

Despite the fact that London was by far the most important destination for the migrants from southern England during the nineteenth century, little research has been done on its effect on southern labor markets. This paper examines the effect of distance from London on agricultural wage rates in southern England and the effect of labor market conditions in London on annual changes in agricultural wage rates. I estimate a series of cross-section regressions to determine the size of the London wage effect at various points in time and to test whether the effect declined during the nineteenth century. I also estimate a timeseries model to explain the determinants of annual changes in agricultural wages in southern England from 1864 to 1904 . The regression results indicate the extent to which changes in agricultural wages were driven by London wage and employment rates, and thus the degree to which rural and urban labor markets were integrated. 
Job Tenure and Employment Structure during High Industrialization: The Case of Germany Before World War I

Analyses of job tenures during the period before World War I have generally been restricted to cross-sectional surveys or the records of firms that maintained longer-term employment histories. These sources typically exclude the service sector, which may have had a different pattern of tenures than firms in transport or manufacturing. This paper uses a new source, the extracts from health insurance records found in the Munich Citizenship Records, that provides employment histories for workers in a wide range of occupations and industries from the early 1890 s to 1914 . Analysis of data quality suggests that it captures the experience of the lower two-thirds of wage earners in Munich. By the standard of today's labor markets, the median job tenure was very short (about one-half year), particularly in manufacturing sectors using traditional technologies and in construction.

JOHN BROWN, Clark University

\section{Employment Patterns of Agricultural Day-Laborers near Sheffield: Gender Differences and Changes over Time, 1772-1775 and 1831-1845}

A unique wage book, containing payments to day-laborers at the same farm in two different time periods, allows me to compare the employment patterns of day laborers in 1772-1775 to those in 1831-1845. I conclude that female employment declined from 17 percent of total work-days in the 1770 s to only 7 percent of work-days in $1831-1845$. This change appears to result from a decline in demand for women's services because the relative wage women received fell as well. Second, female employment was more casual than male employment; most female employment occurred only during a short harvest period. Third, seasonality of male employment changed between the two time periods whereas that of female employment did not. The peak of male employment shifted from late summer to spring.

JOYCE BURNETTE, Wabash College

\section{SESSION 3A: NURTURING BUSINESS: FINANCIAL SYSTEMS AND ECONOMIC PERFORMANCE}

\section{Hugo Stinnes and His Bankers, 1895-1914}

Although recent scholarship has demolished Rudolf Hilferding's thesis that German industry was dominated by finance capital before 1914, much work needs to be done in reconstructing and analyzing the relationship between the universal banks and big business. This paper explores the use made of banks and bankers by Hugo Stinnes (1870-1924) in building up the heavy industrial empire over which he came to preside. Stinnes was extremely dependent on the banks for credit and support but demonstrated a remarkable capacity to organize and manipulate the banking consortia involved. Whereas theory has it that the bankers controlled industrial enterprises through the supervisory board, Stinnes demonstrated that an industrialist with financial power was capable of using the supervisory board effectively to organize and direct concern policy. He treated the bankers as servants of industrial interests. This created some tension, but the bankers were able to exercise only limited control over Stinnes's investment decisions and were highly dependent on his judgment and know-how. 


\section{The Efficiency Consequences of Institutional Changes: Capital Market Regulation and Industrial Productivity Growth in Brazil, 1866-1934}

This paper examines one of the central hypotheses of the New Institutional Economics: that the reform of institutions - the rules and regulations enforced by the state that both permit and bound the operation of markets - is crucial for the process of economic growth. It examines this hypothesis by estimating the productivity gain afforded to Brazilian textile firms by the reform of the regulations governing Brazil's securities markets in 1890 . This analysis is based on panel data regressions on 18 firm-level censuses covering the period 1886 to 1934 , which permit me to decompose total factor productivity growth. These censuses cover both limited liability joint-stock companies as well as privately owned firms. I also analyze corporate financial statements and stock market data for publicly held firms covering the period 1895 to 1940 . The paper argues that the reform of the regulations pertaining to limited liability and mandatory disclosure permitted the widespread use of Brazil's debt and equity markets to mobilize capital for industry. This meant that the capital constraints faced by firms prior to the 1890 s were relaxed. The result was an increased rate of investment, a decline in industrial concentration, and accelerated rates of growth of productivity.

STEPHEN HABER, Stanford University

\section{Financial Institutions and Economic Change: The São Paulo Bolsa, 1886-1914}

This paper assesses the contribution of the São Paulo, Brazil, stock and bond exchange to the region's extraordinary economic growth and diversification at the turn of the twentieth century. I find that the use of the joint-stock format in business formation before 1890 was inhibited by regulatory legislation that saddled shareholders with unlimited liability. Only companies with sufficiently large capitalization to place them beyond the reach of traditional kin-based or community-based finance, principally banks and railroads, used the impersonal markets to raise capital. The introduction of limited liability in 1890 , however, paved the way for extensive use of impersonal capital markets by a broad range of industrial and urban ventures. Two-thirds of all publicly traded companies in 1914 were urban commercial and industrial businesses, compared to none in 1886. Industrial capital listed on the Bolsa, nonexistent before 1890, grew from 10 percent of all listed equity in 1905 to 25 percent by 1914 . Virtually all post- 1900 growth in the cotton-textile sector was financed through the sale of equity capital and bonds. By World War I, the Bolsa was of fundamental importance to the expansion of São Paulo's urban and industrial base.

ANNE HANLEY, Northwestern University

\section{SESSION 3B: THE GOVERNMENT'S POLICY, ADJUSTMENT, AND GROWTH}

The Political Economy of New Deal Expenditures: A Preliminary and Exploratory Investigation

The largest peace-time expansion of the federal government occurred during the 1930 s when the New Deal provided employment for millions of unemployed workers, while adding significantly to the nation's infrastructure. Despite numerous studies of the politics of the New Deal, there are surprisingly few micro-level analyzes of the impact of New Deal 
expenditures on local economic development in the 1930s. Using a previously untapped data set on New Deal spending across U.S. counties during the 1930s, we examine the impact of New Deal spending on local economic development, as well as examining the factors determining the distribution of New Deal funds across counties. Our preliminary results suggest that New Deal spending had a positive effect on the value of real estate wealth, but the effect was not large. The empirical analysis also reconfirms earlier findings that the people distributing New Deal funds tried to promote economic relief and recovery as well as their own political agendas.

PriCE V. FISHBACK AND SHAWN EVERETT KANTOR, University of Arizona

\section{Private Enterprise and the State in Russia: A Comparative Study of the Putilov Company (1866-1917) and the Kirov Works Today}

[No abstract submitted]

JONATHAN GRANT, Florida State University

\section{Convergence in China During the Maoist and Reform Regimes}

A central question in economic history is whether there is a general tendency for poor countries or regions to catch up with richer ones, or whether such convergence only occurs under special circumstances. We estimate the rate of income convergence among Chinese provinces under the Maoist economy (1949-1978) and under the reform economy (1979-1994). There is no evidence for convergence of incomes across all provinces during the Maoist period, but strong convergence emerges in the reform period. Patterns of consumption across provinces differ substantially from income patterns due to transfers across provinces. Consumption converges across provinces in the Maoist period and diverges during the reform period. We argue that in the long run, consumption and income should follow the same convergence patterns.

SUMNER LACROIX, University of Hawaii, Manoa AND RICHARD GARBACCIO, Harvard University

\section{SESSION 4A: THE POLITICS AND ECONOMICS OF COMPETITION: SOME HISTORICAL AND INTERNATIONAL COMPARISONS}

\section{The Politics of International Capital Flows: Canada, Argentina, and the United States}

Over the years 1870 to 1914 , about one-third of all British savings were directed overseas; and about one-half of that total found its was to the four frontier countries. The economic environment and the particular set of financial institutions that evolved in each country were influenced by domestic economic and political consideration-government policies, the experience of businessmen, and the preferences of consumer-but, to the extent the preferences of foreign were not identical to those of domestic savers, they were also influenced by the flow of foreign capital. This paper examines the impact of those international transfers on the institutional structure of the financial markets that emerged in both Britain and in the four receiving countries 
Regulating Competition in the Telecommunications Industry: The United States and Great Britain, 1890-1920

Cutthroat competition is a particularly virulent form of rivalry that can develop in industries characterized by high fixed costs, network externalities, and a tendency toward excess capacity. Though such competition has a controversial reputation, it can be extremely efficacious in spurring firms to invest in new facilities and innovate to lower costs and expand network capacity. Cutthroat competition also presents distinctive challenges to firms and requires an expanded repertoire of strategic behavior to profit from its creativedestructive opportunities. The history of the railroad and telecommunications industries shows how this competition works and why it may have positive long-term results, even if it is only temporary. Differences across nations reveal that government policy can substantially affect the level, timing, and outcomes of this sort of rivalry. Since such competition is inherently unstable, how policy deals with the end of competition can have significant long-term implications.

KENNETH LIPARTITO, University of Houston

\section{On Failure and Success: Two Trade Agreements Between Mexico and the United States}

In January 1884, Matias Romero, plenipotentiary Ministry of Mexico in Washington and Ulysses S. Grant signed the protocol of reciprocity treaty between Mexico and the United States. The American Congress delayed its passage arguing excessive advantages for Mexico while in Mexico public opinion openly rejected the treaty. Even though the treaty was never rejected at an official level, it was abandoned four years later. The failure, however, did not alter the increasing integration of these two economies. By the 1890 s and the 1900s the United States became the most important market for Mexican exports and American imports overcame traditional Mexican suppliers such as Great Britain, France and Germany. On January 1, 1994, the North American Free Trade Agreement created a free-trade zone that sought to increase the integration of Mexico, Canada, and the United States. Nevertheless, trade flows between Mexico and the United States have not changed significantly. The change has operated at the institutional level preventing a return to protectionist policies as well as to guarantee the financial stability of the trade partners.

Graciela MarqueZ, Harvard University

\section{SESSION 4B: A PRECOCIOUS INFANT: THE MARKET IN MEDIEVAL ENGLAND}

\section{A Precocious Infant? The Evolution of the English Grain Market, 1208-1770}

When did England become a market economy, where production was largely for the market and the market was the organizing principle of the economy? Using data on grain yields and prices from large numbers of medieval manors in southern England I test how well the early grain market operated and how extensive it was. The results of the tests of efficiency are consistent with an efficient market that exhausted most profit opportunities from the earliest years. The real force of political and cultural constraints on its operation seem to have been minimal. I also find evidence that the peasantry on the Winchester estates were heavily engaged in the market. 


\section{Matching Supply to Demand: Agricultural Production and Disposal by English Demesnes in the Century of the Black Death}

Medieval historians are reintegrating commercial development and market demand into their analyses of economic change. It is clear that during the twelfth and thirteenth centuries market institutions proliferated, internal and external trade grew apace, and commercial values and relationships penetrated most aspects of social and economic life. Nevertheless, alternative values and relationships persisted and there remained many impediments to the efficient operation of markets. Systematic analysis of data recorded in manorial accounts demonstrates that whereas lords adapted the scale, composition and methods of demesne crop production in accordance with changes in relative prices and the configuration of economic rent, disposal decisions were more likely to be determined by the place of the demesne in question within the estate production system as a whole. The medieval economy was thus a dual economy in which producers and consumers continued to make partial and selective use of the market. Moreover, the momentum of market advance appears to have lost rather than gained ground in the aftermath of the Black Death.

BRUCE M. S. CAMPBELL, The Queen's University of Belfast

\section{Market Networks in the London Region Circa 1400}

Medieval London lay at the heart of a dense network of urban and rural markets with which it interacted at a variety of levels. The largest of England's provincial towns c. 1400 all lay at some distance from London, and much of their trade with the capital involved the higher-valued textiles and other manufactured and imported goods. Closer towns were for the most part small, and many served as gathering centers for agrarian produce destined for consumption in London. Specialized groups of traders and carriers in the city and its hinterland catered to metropolitan demand for food, fuel, and other products and helped to underpin the emergence of agrarian specialization in the countryside. Geographical theory can provide some insights into the operation of this medieval market system.

Jim Galloway, Derek KeEne, AND MaRGaRet MURPHY, University of London

\section{SESSION 5A: GROWTH AND WELL-BEING IN NORTH AMERICA}

\section{Economic Instability in the United States: A Comparison of the 1930s and the 1970s}

In the 1930s, the performance of the American economy was remarkably similar to its performance in the 1970s. In both decades, GDP growth-rates fell after several years of vigorous rise. Unemployment rates reached unprecedented levels and the resultant instability was persistent rather than transitory. At the beginning of each of these decades, profound exogenous shocks triggered the difficulties that followed. On both occasions, as well, formidable political and intellectual obstacles prevented the adoption and implementation of appropriate counter-cyclical policies. In all these similarities are to be found keys to understanding the causes of the instability of these two periods. Moreover, they suggest that the contemporary relevance of our understanding of the Great Depression of the $1930 \mathrm{~s}$ is more substantial than has generally been believed. 


\section{Social Status and Health among Older Men: A Comparison Between 1900 and the Present}

I compare the size of health disparities by social class in 1900 and the present among white, middle-aged, American men. I find that circa 1900 social class differences in yearly mortality rates were similar to those today, largely because in the $1900 \mathrm{~s}$ infectious disease equalized deaths across socioeconomic groups. In contrast, reductions in occupational stress produced dramatic declines in health disparities in BMIs and cardiovascular and rheumatic rates and substantial improvements in average health. The impact of occupational stress was particularly evident among farmers. Although farmers were by far the healthiest men in terms of BMIs and heights among men 25 to 34 years old, by their fifties they fared much worse than professionals and proprietors and about as well as artisans and laborers in terms of BMIs and chronic disease rates. Relatively favorable childhood conditions, as proxied by tall height, were not enough to protect men against the ravages of occupational hazards. By concentrating on heights economic historians may have underestimated the extent of poor health both in subgroups of the American population and in the population as a whole.

DORA L. COSTA, Massachusetts Institute of Technology and NBER

\section{Long Swings in Growth in Colonial North America: A Comparison of Development in the Thirteen Colonies and Canada}

Economic historians have found the concept of "long swings" useful. Most scholars agree that economic activities have moved in patterns that are longer than the business cycle. This paper applies that conceptual approach to the seventeenth and eighteenth centuries, and explores the Thirteen Colonies and early Canada. The presentation argues the key to the timing of cycles in North America was the long swings in the metropolitan power. To a remarkable degree the New World dominions were the creatures of the European country that had established them. So the French economy defined for Canada two broad cycles of growth, 1660-1713 and 1713-1760; while the British economy had a similar impact on the Thirteen Colonies, mapping out a pair of long swings, 1713-1745 and 1745-1775.

MARC EGNAL, York University

\section{SESSION 5B: FINANCING AND DISTRIBUTING}

\section{The Relative Productivity of American Distribution, 1869-1992}

This paper assesses the distribution's contribution to growth in aggregate output per worker between 1869 and 1992, particularly in comparison to manufacturing. A sector's contribution to growth in aggregate labor productivity is defined as change in sectoral productivity times labor force share plus change in labor force share times level of sectoral productivity. Over the entire period, manufacturing contributed more than trade to labor productivity growth. Nevertheless, for 10 of the 19 short examined, trade outdistanced manufacturing. Between 1869 and 1909 trade contributed almost as much as manufacturing. Between the 1960 s and 1992, and most likely between 1849 and 1869 , it contributed more. The paper goes on to explore the implications and determinants of these trends within a broader technological, organizational, and legal framework. 
The Cultural Construction of Cash: Credit and Ready Money in English Consumer Relations Circa 1770-1900

Since the publication of the Wealth of Nations in 1776, much writing on the history of economic thought in England has been dominated by the labor theory of value and the gold of market mechanisms in establishing the "natural" price of commodities. This paper explores markets and prices from a somewhat different vantage point, by focusing on the liabilities of the implicit assumption-embedded in the Wealth of Nations-that commercial transactions in England typically occurred on a cash basis. For Smith, cash prices represented the unspoken norm of economic exchange, but for English men and women of the later eighteenth and nineteenth centuries credit purchasing was the essence of quotidian consumption. Historians' preoccupation with the labor theory of value and the concept of the free market has tended to shift attention away from analysis of the myriad cultural forces that served, historically, to distort and inflate the market price of goods relative to associated with status and class on the sale of retail goods on credit, exploring the ways in which upper-class consumers' credit expectations shaped the retail environment. As examination of such transactions reveals the danger of accepting at face value contemporaries' distinction between "cash" and "credit" sales. For English retailers routinely adjusted the definition of a "cash" sale to reflect the social status of their customers. An understanding of the cultural construction of "cash" in England complicates both Smith's simplistic model of price determination and subsequent historians' analyzes of the nature of cash and credit retail markets in the nineteenth century.

MARGOT FINN, Emory University

\section{Lending Clienteles and the Institutions of Public Finance in Early Modern France}

This article examines who the lenders were who supported the financial intermediation of privileged corps. Provincial Estates were more successful than venal officer corps in piecing together a wide clientele of lenders, suggesting that investor confidence in provincial Estates was the highest of all intermediating corps. Estates' ability to assert independent control over the revenues that guaranteed the reimbursement of their loans enabled them to develop the reputation needed to attract such a wide array of lenders.

MARK POTTER, University of California, Los Angeles 